\title{
Characterization of gene family that mediates the adhesion of biofilms formed by Candida tropicalis isolated from HIV and non-HIV patients
}

\author{
PM Punithavathy, Thangam Menon* \\ From First International Science Symposium on HIV and Infectious Diseases (HIV SCIENCE 2012) \\ Chennai, India. 20-22 January 2012
}

\section{Background}

Candida tropicalis is an important cause of candidemia in immunocompromised patients. Biofilm formation helps the organism to establish infection. Agglutinin like sequence (ALS) genes encodes glycoproteins which are important adhesins. This study was done to detect the presence of ALS genes by PCR in C.tropicalis strains isolated from HIV and non-HIV patients in comparison with biofilm formation.

\section{Materials and methods}

Yeast isolates: A total of 48 C.tropicalis isolates (HIV-20; non-HIV-28) were included in this study. Biofilms were formed on 96 well plates as described earlier and ALS genes were detected by PCR using specific primers.

\section{Results}

Among the 48 C.tropicalis isolates, 16 out of 20 (80\%) HIV isolates and 17 out of 28 (61\%) non-HIV isolates were biofilm producers; 4 out of 20 HIV isolates (20\%) and 11 out of $28(39 \%)$ non HIV isolates were biofilm non-producers. Out of 48 isolates, 12/48 (25\%) isolates were positive for ALS $1 ; 24 / 48$ (50\%) isolates were positive for ALS 2; 23/48 (48\%) isolates were positive for ALS 3. Thirty four out of 48 (71\%) isolates were positive for one or more ALS genes. Twenty two of the 34 (65\%) were biofilm producers. Of the 14 strains which were negative for all ALS genes, 11 (79\%) were biofilm producers.

\section{Conclusion}

ALS 2 and ALS 3 genes were more common in C.tropicalis than ALS 1. The biofilm forming ability of the strains was independent of the presence of the ALS genes and the source of the isolates.

Published: 4 May 2012

\section{doi:10.1186/1471-2334-12-S1-O8}

Cite this article as: Punithavathy and Menon: Characterization of gene family that mediates the adhesion of biofilms formed by Candida tropicalis isolated from HIV and non-HIV patients. BMC Infectious Diseases 2012 12(Suppl 1):O8.

* Correspondence: punits.micro@gmail.com

Dr. ALM Post Graduate Institute of Basic Medical Sciences, University of Madras, Taramani, Chennai, India

Submit your next manuscript to BioMed Central and take full advantage of:

- Convenient online submission

- Thorough peer review

- No space constraints or color figure charges

- Immediate publication on acceptance

- Inclusion in PubMed, CAS, Scopus and Google Scholar

- Research which is freely available for redistribution
C Biomed Central

\section{() Biomed Central}

